\title{
Unidad de Investigación
}

\section{Formato informe de avance del proyecto FODEIN 2018}

\section{Información general}

1. Información general del proyecto, diligencie el siguiente cuadro según corresponda:

\begin{tabular}{|l|l|}
\hline Código interno & 1818005 \\
\hline Título del proyecto & CAPAZ- TIERRAS \\
\hline Programa académico & Derecho \\
\hline Nombre de investigador(es) & Ricardo Durán Vinazco \\
\hline $\begin{array}{l}\text { Nombre de auxiliares/estudiantes } \\
\text { de semillero/jóvenes }\end{array}$ & No hay \\
investigadores & \\
\hline Descripción detallada de los & \\
productos alcanzados a la fecha & Artículo de investigación titulado \\
& DERECHO A LA PROPIEDAD EN EL \\
& PROCESO DE PAZ EN COLOMBIA: \\
& APROXIMACIÓN AL RÉGIMEN JURÍDICO DE \\
& LOS BALDÍOS, FRENTE A LOS ACUERDOS \\
& DE PAZ CON LAS FARC: UN ANÁLISIS \\
& PROSPECTIVO, Publicado en el libro PAZ \\
& TERRITORIAL Y TIERRAS UNA MIRADA \\
& CRÍTICA A LOS ACUERDOS DE LA HABANA. \\
\hline Porcentaje estimado de avance & ISBN 978-958-749-878-3 \\
\hline Ejecución presupuestal a la fecha & No0\% \\
(si aplica) & No aplica \\
\hline Fecha del avance & 17 de julio de 2018 \\
\hline
\end{tabular}




\section{Contenido}

2. Contenido con formato tipo artículo de divulgación para la Revista Sol de Aquino (Ver anexo), debe contener los siguientes elementos:

2.1. Título: DERECHO A LA PROPIEDAD EN EL PROCESO DE PAZ EN COLOMBIA: APROXIMACIÓN AL RÉGIMEN JURÍDICO DE LOS BALDÍOS, FRENTE A LOS ACUERDOS DE PAZ CON LAS FARC: UN ANÁLISIS PROSPECTIVO.

2.2. Resumen: se hace un breve análisis en el marco de Los Acuerdos de La Habana, sobre la falta de censo de los terrenos baldíos en Colombia, para la conformación del Fondo de Tierras en desarrollo de dichos Acuerdos, especialmente en lo referente al modo adquisitivo del dominio previsto en la ley para este tipo de inmuebles. Esta problemática se centra en que dichos inmuebles están siendo adquiridos por el modo de Prescripción del artículo 2512 del Código Civil y no mediante el modo de la Ocupación previsto en el artículo 65 de la Ley 160 de 1994, en desarrollo del artículo 150 \#18 de la Constitución Política. De esta forma una de las causas para no poder realizar el censo de los baldíos es que dichos inmuebles han venido siendo adquiridos por los particulares por un modo que no corresponde con el autorizado en la ley. Censo indispensable para la implementación de la Paz Territorial, la realización de una mejor distribución de la tierra, ordenamiento territorial y recaudo fiscal.

2.3. Abstract: a brief analysis is made within the framework of the Havana Agreements, on the lack of census of the uncultivated lands (Baldío) in Colombia, for the conformation of the Land Fund in development of said Agreements, especially as regards the purchasing mode of the planned domain in the law for this type of property. This problem centers on the fact that said properties are being acquired by the way of Prescription of article 2512 of the Civil Code and not by the way of the Occupation foreseen in the article 65 of the Law 160 of 1994, in development of the article 150 \# 18 of the Political Constitution. In this way, one of the reasons for not being able to carry out the census of the vacant lots is that said properties have been acquired by private individuals in a way that does not correspond to that authorized by law. Essential census for the implementation of the Territorial Peace, the realization of a better distribution of the land, territorial ordering and fiscal collection.

2.4. Palabras clave: Acuerdos de La Habana, baldíos, modos de adquisición, ocupación, prescripción, catastro multipropósito.

2.5. Key words: Havana Agreements, Vacant uncultivated lands (Baldío), Occupation, Prescription, census multipuepose.

2.6. Objetivo general: probar cómo algunos baldíos en Colombia vienen siendo adquiridos por el modo de la Prescripción y no por el de la Ocupación, lo que se constituye en una de las causas para que no se pueda realizar un censo de baldíos en Colombia fiable, como herramienta de las políticas públicas, y al mismo tiempo incida en el cumplimiento de la conformación del Fondo de Tierras en el marco de Los Acuerdos de La Habana.

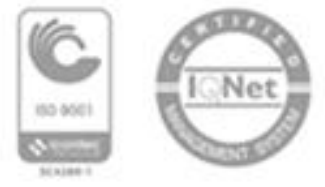


2.7. Metodología: descriptivo, inductivo y deductivo a partir de fuentes primarias sentencias- y secundarias - doctrina y ley-.

2.8. Resultados parciales y/o esperados: Desde los Acuerdos de La Habana en materia de tierras se intentó una reforma agraria en Colombia, para lo cual se conformó un Fondo de Tierras, uno de cuyos componentes son los baldíos que deben ser recuperados de manos de los particulares, los cuales los han adquirido sin cumplir con los requisitos de ley. En Colombia la apropiación de los baldíos por los particulares sin el cumplimiento de la ley no es otra cosa que la pérdida del patrimonio público, por razones históricas que se pueden rastrear desde antaño y que hogaño corresponden a un desorden institucional, lo que se refleja en que sin la certeza de que un inmueble sea de propiedad particular, es decir, existiendo indicios de que es un bien baldío, se hayan declarado adquiridos por los particulares usando el proceso de pertenencia acudiendo al modo de la prescripción. Paradójicamente esa circunstancia ha llevado a un enfrentamiento entre las dos ramas del poder público, la judicial que declara la pertenencia del baldío y la administrativa que censa y lleva el registro de los inmuebles, tensión que ha sido llevada al control del juez de tutela quien gracias a su intervención ordenó poner orden empezando por establecer el censo y ordenando a los interesados tomas medidas para la solución del problema, lo cual se expresa a través de una serie de instrucciones administrativas que por lo menos ofrecen claridad conceptual para saber de qué se trata. Cualquiera sea la lectura que se haga del proceso histórico al cual conducen los Acuerdos de La Habana, cada pueblo construye su historia y este camino es la esperanza de que con los problemas que sean se avanza en la ruta correcta aunque siempre habrán soluciones más eficientes y por lo tanto inteligentes. Es la primera vez, que se sepa, que se adopta una Política Pública sobre un bien escaso como es la tierra, no sólo para censarlo sino para su administración y manejo legal. (Durán R., 2018, p. 328) 